\begin{tabular}{|c|c|c|}
\hline 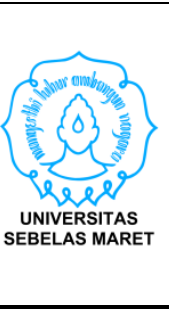 & $\begin{array}{l}\text { DWIJA CENDEKIA: Jurnal Riset Pedagogik } 4 \text { (2) (2020) 247-256 } \\
\text { DWIJA CENDEKIA } \\
\text { Jurnal Riset Pedagogik } \\
\text { https://jurnal.uns.ac.id/jdc }\end{array}$ & 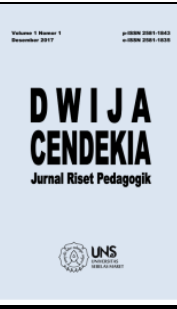 \\
\hline
\end{tabular}

\title{
Eksisitensi Program Sekolah Mitra Rumah pada Sekolah Alam Tangerang Banten
}

\author{
Siti Munawati ${ }^{1}$, Nur Halimah ${ }^{2}$, Abdul Manan $^{3}$ \\ 1,2 UNIS Tangerang Banten \\ ${ }^{3}$ SPs UIN Syarif Hidayatullah Jakarta
}

\section{Sejarah Artikel}

diterima 28 Oktober 2020 disetujui 20 November 2020 diterbitkan 1 Desember 2020

\begin{abstract}
The home partner school program is the Work With Parents (WWP) Program, which is designed to strengthen the responsibilities of all parties between parents and the school by calling it the Aqil Baligh curriculum. The generalization of this curriculum is to educate students as the younger generation so that they are ready to become a generation that is mature and moral, and has a personality to be mature and responsible. The goal is that parents during the period of an online learning system can influence learning for their children at home. This research uses a qualitative methodological approach, in the program data collection technique (WWP) which is carried out by triangulation (combined), and data analysis is qualitative in nature and parents become role models for their children in the stage of entering adulthood and are responsible for their environment, social, and culture.

Keywords: Aqil Baligh, Talent, Curriculum
\end{abstract}

\begin{abstract}
Abstrak
Program sekolah mitra rumah yaitu Program Work With Parents (WWP) yang dibuat agar tangggung jawab dari semua pihak yang ada saling menguatkan antara orang tua dengan sekolah dengan menamakannya kurikulum Aqil Baligh. Generalisasi Kurikulum ini untuk mendidik peserta didik sebagai generasi muda agar siap menjadi generasi yang matang dan berakhlak, dan memiliki pribadi menjadi sosok yang matang dan bertanggung jawab. Tujuannya agar orangtua pada masa pendemi sistem pembelajaran berupa online, dapat mempengaruhi pembelajaran bagi anak-anaknya di rumahnya. Penelitian ini menggunakan pendekatan metodologi kualitatif, dalam tehnik pengumpulan data program (WWP) yang dilakukan secara triangulasi (gabungan), dan analisa data bersifat kualitatif dan orang tua menjadi tauladan bagi anak-anaknya dalam tahap memasuki kedewasaan serta bertanggung jawab terhadap lingkungannya, sosialnya, serta budayanya.
\end{abstract}

Kata kunci: Aqil Baligh, Generasi, Kurikulum 


\section{PENDAHULUAN}

Untuk menunjang keberhasilan pembelajaran, dasarnya adalah menentukan pendekatan pembelajaran yang sejalan dengan kurikulum. Pendidikan merancang kurikulum yang mencakup pengetahuan terkini, dengan guru yang memiliki pengetahuan tentang kurikulum dari tingkat perkembangan pembelajaran yang mengajarkan dan mengetahui penempatan siswa sesuai kemampuan akademis melalui evaluasi.(Berry, n.d.).

Tujuan pendidikan adalah hal pertama dan terpenting bila kita merancang, membuat program, serta mengevaluasi pendidikan, jadi tujuan pendidikan sama dengan tujuan manusia. Manusia menginginkan semua manusia, termasuk anak keturunannya, menjadi manusia yang baik. Sampai di sini tidaklah ada perbedaan antara manusia dengan orang lain. Perbedaan akan muncul tatkala merumuskan ciri-ciri manusia yang baik itu. (Tafsir, n.d.)

Akil baligh adalah seseorang yang sudah sampai pada usia tertentu untuk dibebani hukum syariat (taklif) dan mampu mengetahui atau mengerti hukum tersebut. proses penyiapan warga negara, maupun sebagai proses pewarisan budaya dari generasi ke generasi mengarah kepada kegiatan pembimbingan terhadap umat manusia agar dapat mempertahankan kelangsungan dan kelayakan hidupnya sebagai manusia. Ini mengandung pengertian bahwa selain menyiapkan generasi agar dapat mengembangkan potensi sebagai bekal dasar untuk mempertahankan kelangsungan hidupnya, pendidikan juga bertanggung jawab untuk melaksanakan tugas pembimbingan dalam bidang moral dan agama agar mereka dapat hidup layak sebagai manusia sehingga terwujudlah suatu tatanan kehidupan yang manusiawi, bermoral, dan berakhlak mulia.

Sekolah Alam pada dasarnya adalah bentuk pendidikan alternatif yang menggunakan alam semesta sebagai tempat belajar, bahan mengajar juga sebagai obyek pembelajaran. Dengan konsep pendidikan ini para siswa diharapkan bisa belajar dari alam lingkungan sekitar dan mengaitkan pelajaran serta menerapkan ilmu yang didapat dengan kehidupan nyata sehari-hari.(Satmoko Budi Santoso, n.d.)

Keunikan dari Sekolah Alam secara pembelajaran dilakukan bukan oleh semua guru mata pelajaran akan tetapi ada program sekolah mitra rumah. Merupakan program yang dibuat sekolah agar tangggung jawab dari semua pihak yang ada di Sekolah Alam termasuk adanya sinergi rumah sekolah yang menguatkan program dalam kerjasama antara orang tua dengan sekolah melalui program sekolah mitra rumah.(Dokumen, n.d.)

Fenomena di masyarakat pada saat ini tidak sedikit orangtua murid yang mengalami disfungsi perannya sebagai orangtua, bahkan abai terhadap pentingnya menginjeksi pemahaman yang benar, utuh, dan meluhurkan tentang masalah seks (Adriano Rusfi, n.d.), seksualitas atau kesehatan reproduksi kepada anaknya saat jelang usia akil baligh, maka para guru perlu mengambil peran itu demi menyelamatkan pemahaman anak didiknya dari kemungkinan munculnya pemahaman dan perilaku keliru dan menjerumuskan. (Adriano Rusfi, n.d) $\begin{array}{llr}\text { Sekolah Alam mengajak para } & \text { merancang } \\ \text { orangtua } & \text { untuk } & \text { merancang } \\ \text { pembelajaran yang } & \text { memberikan }\end{array}$ 
makna kepada setiap anak melalui Program Work With Parents (WWP) dan program individual yang diperlukan oleh setiap anak. Melalui program yang juga dilakukan oleh orang tua di rumah, sekolah berdasarkan program tersebut sangat terbantu dalam pelaksanaan programprogram setiap anak didik.

Selain membantu dalam menguatkan pemahaman mengenai pengalaman yang sudah didapatkan di sekolah, program WWP juga melatih kemandirian anak yang memang membutuhkan peran orang tua, sebagai pasangan dengan pendidikan tinggi adalah yang paling mungkin untuk berbagi dengan orang tua. Cara alternatif untuk memenuhi peran orang tua yang baik, peran di mana ia memasukkan unsur digambarkan sebagai orang tua sekunder dan primer, memikul tanggung jawab untuk kehidupan keluarga dan kesejahteraan anak-anak yang berorientasi pada anak pemahaman dan pengalaman, (Marie Evertsson, n.d.) untuk melatihnya. Manfaat WWP ini dirasakan bukan hanya oleh guru disekolah. Namun orang tua juga merasakan manfaat WWP.

Rumusan masalah yang penulis tuangkan adalah: Pertama Bagaimana peran sekolah dalam menyusun konsep kuriulum Aqil Baligh ? Kedua Apa peran orangtua dalam Program WWP yang diterap sekolah untuk anak-anaknya di rumah?

\section{METODE}

Berdasarkan pada tujuan penelitian, jenis penelitian ini merupakan penelitian yang dilakukan adalah penelitian lapangan (field research), (Carol A. Bailey, n.d.), yaitu dengan tinjauan lapangan demi memperoleh data yang valid agar kebenarannya dipertanggung jawabkan (Nurhasanah, n.d.)

Program sinergi rumah sekolah yang menguatkan program dalam kerjasama antara orang tua dengan sekolah melalui program sekolah mitra rumah. Penelitian ini bermula dari yang kenyatan yang ada dan sudah diketahui banyak pihak, yang nantinya akan menghasilkan sebuah konsep baru.

Penelitian ini menggunakan pendekatan kualitatif (qualitative) yang merupakan sebuah prosedur penelitian yang menghasilkan data deskriptif berupa kata-kata atau tulisan dari orang-orang dan perilaku yang diamati. Metode penelitian yang berlandaskan pada filsafat post positivisme, digunakan untuk meneliti pada kondisi obyek yang alamiah, (sebagai lawannya adalah eksperimen) di mana peneliti adalah sebagai instrument kunci, tehnik pengumpulan data dilakukan secara triangulasi (gabungan), analisa data bersifat kualitatif, dan hasil penelitian kualitatif lebih menekankan makna dari pada generalisasi.(Sugiyono, n.d.) Analisa data merupakan kegiatan yang dilakukan oleh peneliti setelah data terkumpul.(Iskandar, n.d.) Analisa data Sekolah Alam yang mengajak para orangtua untuk merancang pembelajaran yang memberikan makna kepada setiap anak melalui Program Work With Parents (WWP) dan program individual yang diperlukan oleh setiap anak. Melalui program yang juga dilakukan oleh orang tua di rumah, sekolah berdasarkan hal tersebut sangat terbantu dalam pelaksanaan 
program-program setiap anak didik, yang memang dilakukan dengan sejak awal pengumpulan data, dengan cara menyeleksi data, mereduksi dan mengklarifikasi data yang telah terkumpul. Kemudian untuk mendeskripsikan mengenai pola-pola pengembangannya wewujudkan sikap kearah perubahan yang lebih baik digunakan teknik deskriptif analisis, yaitu mendeskripsikan temuan-temuan di lapangan, melakukan wawancara, pengamatan (observing), menafsirkan (interpreating), dan selanjutnya melakukan analisisi akhir.

\section{PEMBAHASAN}

\section{A. Penerapan Kurikulum Aqil Baligh di sekolah Alam}

Keberagaman dipandang sebagai sesuatu yang unik di Sekolah Alam, dan keseragaman tidak dipandang dari apa yang dikenakan, tapi pada akhlak perilaku dan sikap serta semangat belajar dan rasa ingin tahu peserta didik. Dengan demikian pemahaman peserta didik terhadap materi pembelajaran bersifat integratif, komprehensif dan aflikatif. Kemampuan dasar yang ditumbuhkan pada peserta didik di Sekolah Alam adalah kemampuan membangun jiwa keingin tahuan, melakukan obsevasi, membuat hipotesis, serta berpikir ilmiah.

Salah satu metode yang dikembangkan dengan adanya metode "spider-web" yang diterapkan pada peserta didik di sekolah Alam, belajar tidak hanya mendengar penjelasan guru tetapi juga dengan melihat, menyentuh, merasakan dan mengikuti seluruh proses dari setiap pembelajaran. Guru memfasilitasi peserta didik berinteraksi dengan alam dalam rangkaian tema/proyek pembelajaran sedemikian rupa sehingga peserta didik mendapatkan pemahaman yang holistik tentang alam semest

Kurikulum yang dikembangkan di Sekolah Alam, perpaduan antara kurikulum 2013 dengan kurikulum
Sekolah Alam Tangerang sangatlah diperlukan untuk mencapai output peserta didik. Kurikulum yang dikembangkan berdasarkan prinsip bahwa peserta didik memiliki posisi sentral untuk mengembangkan kompetensinya agar menjadi manusia yang beriman dan bertakwa kepada Allah SWT, berakhlak mulia,ialah budi pekerti, watak, kesusilaan (kesadaran etik dan moral) yaitu kelakuan baik yang merupakan akibat dari sikap jiwa yang benar terhadap khaliknya dan terhadap sesama manusia, (Sjarkawi, n.d.). sehat, berilmu, cakap kreatif, mandiri dan menjadi warga negara yang demokratis serta bertanggung jawab.

Untuk mendukung pencapaian tersebut pengembangan kompetensi peserta didik di sesuaikan dengan potensi, perkembangan, kebutuhan, dan kepentingan peserta didik serta tuntutan lingkungan. Memiliki posisi sentral berarti kegiatan pembelajaran berpurat pada peserta didik.

Pengembangan kurikulum dilakukan dengan melibatkan pemangku kepentingan (stakeholders) untuk menjamin relevansi pendidikan dengan kebutuhan kehidupan, termasuk di dalamnya adalah kehidupan kemasyarakatan, dunia usaha dan dunia kerja.

Oleh karena itu, pengembangan keterampilan pribadi, keterampilan 
berpikir, keterampilan sosial, keterampilan akademik, dan keterampilan vokasional merupakan keniscayaan. Sehingga perlu adanya sumber belajar yang memiliki fungsi untuk meningkatkan produktivitas pembelajaran dengan jalan mempercepat laju belajar dan membantu guru untuk menggunakan waktu secara lebih baik dan mengurangi beban guru dalam menyajikan informasi, sehingga dapat lebih banyak membina dan mengembangkan gairah.

Tujuan dari sumber belajar memberikan kemungkinan pembelajaran yang sifatnya lebih individual, dengan cara: (a) mengurangi kontrol guru yang kaku dan tradisional; dan (b) memberikan kesempatan bagi siswa untuk berkembang sesuai dengan kemampuannnya. Memberikan dasar yang lebih ilmiah terhadap pembelajaran dengan cara: (a) perancangan program pembelajaran yang lebih sistematis; dan (b) pengembangan bahan pengajaran yang dilandasi oleh penelitian. Lebih memantapkan pembelajaran, dengan jalan: (a) meningkatkan kemampuan sumber belajar; (b) penyajian informasi dan bahan secara lebih kongkrit. Memungkinkan belajar secara seketika, yaitu: (a) mengurangi kesenjangan antara pembelajaran yang bersifat verbal dan abstrak dengan realitas yang sifatnya kongkrit; (b) memberikan pengetahuan yang sifatnya langsung. Memungkinkan penyajian pembelajaran yang lebih luas, dengan menyajikan informasi yang mampu menembus batas geografis. Fungsi-fungsi di atas sekaligus menggambarkan alasan dan arti penting sumber belajar untuk kepentingan proses dan pencapaian pembelajaran siswa. (Depdiknas, n.d.)

\section{B. Visi, Misi, dan Tujuan Pendidikan Sekolah Alam}

1. Visi Sekolah

Mendidik Pribadi Yang Karena Kematangan

Dan

Kedewasaannya Mampu Menjadi Gembala Alam Yang Bertanggung Jawab Kepada Allah (Khalifatullah Fil-Ardh). Berbekal Sikap Hidup Yang Harmonis Terhadap Alam Dan Tekad Untuk Menjadi Rahmat Bagi Alam Semesta“

a. Misi Sekolah menjadikan sebuah ekosistem bagi matangnya generasi harmoni serta mengakrabi alam bagi penemuan dan penerapan jati diri imani

b. Tujuan Pendidikan

Tujuan Pendidikan dasar adalah meletakkan dasar kecerdasan,

pengetahuan, kepribadian, akhlak mulia, serta keterampilan untuk hidup mandiri dan mengikuti pendidikan lebih lanjut.

c. Tujuan Sekolah, membentuk peserta didik menjadi pribadi 'Ulil Albab yang mandiri, pantang menyerah, dan selalu berkontribusi kepada lingkungan sekitarnya. Memberikan kesempatan kepada peserta didik untuk tumbuh dan berkembang sesuai usia perkembangannya. Menumbuhkan sikap cinta kepada Allah SWT, Rasulullah SAW dan Al-Qur'an, jujur, bertanggung jawab, tabah, sederhana, berani, kritis, kreatif, kontributif, solutif, mandiri, peduli dan kerjasama. Memberikan kesempatan kepada peserta didik untuk menemukan bakatnya melalui beragam aktvitas, banyak 
2. Slogan

aktivitas dan bertemu banyak orang. Menjadi laboratorium pendidikan karakter.

"Berkarakter kuat, Berfikir integral, berdaya juang tinggi, menebar rahmat" (Dokumen, n.d.) Sinergi rumah sekolah memiliki peran yang penting dalam pendidikan anak. Pada saat orang tua memasukan anaknya kesebuah sekolah pada dasarnya hal tersebut adalah bentuk akad kerjasama orang tua kepada sekolah sebagai mitra dalam mendidik anakanak.

Pendidikan anak sendiri sesungguhnya merupakan tanggung jawab orang tua. Sekolah dalam hal ini guru sebagai pendidik hanya membantu sementara para orang tua dalam mendidik anak-anak. Fungsi ini harus benar-benar dipahami sehingga sinergi antara sekolah dengan rumah bisa menciptakan suasana yang positif dalam mendidik anak.

Kurangnya pemahaman mengenai bagaimana mendidik anak juga menjadi hal yang menyebabkan banyak orang tua yang tidak tahu bagaimana menerapkan pola asuh yang benar dirumah. Sekolah dan rumah dalam hal ini dapat bersinergi dalam rangka menguatkan pemahaman dalam penerapan pola asuh yang positif.

Sekolah Alam yang mengajak para orangtua untuk merancang pembelajaran yang memberikan makna kepada setiap anak melalui Program Work With Parents (WWP) dan program individual yang diperlukan oleh setiap anak, yaitu dengan menamakannya kurikulum Aqil Baligh. Pendidikan Aqil Baligh sesuai dengan fungsinya sebagai proses pembentukan pribadi, Akil baligh (Bahasa Arab: 'aqala = berakal, mengetahui, atau memahami; balagha
= sampai).(Ensiklopedi-hukum-islamakil-baligh-1, n.d.). Baligh merupakan sebuah fase yang paling penting dalam Islam, baik dalam perspektif normatif maupun sosial. Menurut Sulaiman Rasjid adalah "orang yang sudah cukup berumur lima belas tahun, keluar mani, mimpi basah dan mulai keluar haid bagi perempuan" (Rasjid, n.d.)

Awal baligh terjadi saat manusia mengalami fase remaja, di mana remaja dan awal baligh secara bilogis memiliki tanda-tanda yang sama. Papila dan Olds masa remaja merupakan masa antara anak-anak dan dewasa. (Jahya, n.d.)

Penerapan kurikulum ini tidak akan mungkin bisa dilaksanakan tanpa peran orang tua sebagai pendidik sejati. Guru disekolah adalah partner orang tua dalam mendidik anak anak. Kami bekerjasama merancang dan melaksanakan berbagai program untuk menstimulasi agar aqil muncul seiring dengan balighnya. Menurutnya " banyak mahasiswa S3 yang usianya sudah 27 tahun belum aqil dimana hidup mereka kebanyakan 100\% ditopang orang tua, kemandirian belum punya dan mudah putus asa. Pendidikan kita saat ini sedang menyiapkan generasi baligh non aqil ini. Anak-anak kita dituntut fokus belajar, sehingga tak perlu memikirkan masalah, mencari nafkah, memasak, mencuci pakaian sendiri, berjuang mengatasi hidup. Sejak 2010, perumusan kurikulum pendidikan aqil baligh mulai disusun dan secara bertahap dilaksanakan di Sekolah Alam Tangerang. Dengan memperhatikan fitrah setiap anak, stimulasi dilakukan dengan memperhatikan setiap tahapan perkembangan. (Rusfi, n.d.) Melalui program Sekolah Mitra Rumah, kami bersinergi untuk 
mewujudkan. Adanya ranah kepribadian merupakan pembelajaran yang kolaborasikan oleh sekolah Alam kedalam mata pelajaran. Ranah kepribadian yang dimaksud sebagai pola sifat dan karakteristik tertentu yang relatif permanen dan memberikan pengaruh, baik konsistensi maupun individualitas pada perilaku seseorang.

Dalam hal ini sifat (trait) merupakan faktor penyebab adanya perbedaan antar individual dalam perilaku dari waktu kewaktu, dan stabilitas perilaku dalam berbagai situasi. Pemakaian istilah kepribadian biasanya disamakan dengan keterampilan atau kecakapan sosial. Kepribadian individu dinilai berdasarkan kemampuannya memperoleh reaksi-reaksi positif dari berbagai orang dalam berbagai keadaan. Selain itu kepribadian individu juga dipandang sebagai kesan yang paling menonjol atau paling kentara yang ditunjukan seseorang terhadap segala macam tingkah laku berbeda-beda yang dilakukan individu termasuk didalamnya usaha-usaha menyesuaikan diri yang beraneka ragam namun khas yang dilakukan oleh tiap individu.(Jess Feist and Gregory J. Feist, n.d.)

Oleh karena itu sifat dipahami sebagai sesuatu yang unik, bisa sama pada beberapa kelompok manusia atau sifat dapat dimiliki semua manusia, namun pola atau bentuk sifat pada masing-masing individu berbedabeda.

\section{C.Target Kompetensi Kurikulum Aqil Baligh di Sekolah Alam}

Baligh merupakan istilah dalam hukum Islam yang menunjukkan seseorang telah mencapai kedewasaan. Baligh diambil dari bahasa arab yang secara bahasa memiliki arti "sampai" maksudnya telah sampainya usia seseorang pada tahap kedewasaan.(Lestari, n.d.)

Dalam dokumen sekolah Alam definisi dewasa dengan istilah usia sekolah adalah remaja yang artinya Masa remaja dimulai pada usia mulai sekitar 12 sampai 21 tahun. Pada masa inilah remaja memasuki masa pubertas. Organ-organ seks, kelenjar seks dan pituary mulai matang. Remaja mulai tertarik dengan lawan jenisnya. Fenomena pacaran sampai seks bebas adalah efek dari kematangan seksual yang tidak di barengi dengan kedewasaan sikap.

Pada masa pendemi ini sistem pembelajaran berupa online juga di sekolah Alam ini, dan memang mempengaruhi pembelajaran bagi peserta didik di rumahnya, hal dipengaruhi juga oleh pola asuh orang tua untuk mengawasi dan mendampingi yang dikhawatirkan bisa melihat situs-situs (porno, kekerasan, atau menonton film yang yang tidak menddidik) yang memang tidak layak untuk dilihat, jadi orang tua yang mendampingi untuk memberikan perhatian, teguran dan pengertian. Sehingga yang diterapkan oleh orangtua sangat mempengaruhi proses aqil baligh, dimana orangtua mencontohkan bagaimana hidup dengan lingkungan sosial, lingkungan budaya, dan perilaku orangtua yang ditampilkan ketika bersama-sama dengan anak-anaknya di rumah.

Kesenjangan antara pubertas dengan kedewasaan ini menyebabkan berbagai masalah. Tawuran, narkoba, seks bebas, dan lain-lain. Jadilah sosok remaja yang terjebak antara ingin dianggap dewasa, tapi belum mampu menjadi dewasa. Fenomenanya saat ini makin banyak muncul ke permukaan melalui berbagai kasus. (Dokumen, n.d.) 
Masa tahapan Masa remaja dimulai pada usia mulai sekitar 12 sampai 21 tahun. Pada masa inilah remaja memasuki masa pubertas. Organ-organ seks, kelenjar seks dan pituary mulai matang. (Papalia, Diane. E, n.d.)

Remaja, menurut Annelies Kamp merupakan hasil dari proses kumpulan itu adalah konsekuensi dari wacana yang beragam, konstruksi budaya, struktur sosial, proyeksi ekonomi dan keterikatan emosional yang menyatu dalam kepedulian terhadap kaum muda, untuk anakanak, untuk masa depan yang mereka miliki (Mcsharry, n.d.), mulai tertarik dengan lawan jenisnya. Fenomena pacaran sampai seks bebas adalah efek dari kematangan seksual yang tidak di barengi dengan kedewasaan sikap. Kesenjangan antara pubertas dengan kedewasaan ini menyebabkan berbagai masalah. Tawuran, narkoba, seks bebas, dan lain-lain. Jadilah sosok remaja yang terjebak antara ingin dianggap dewasa, tapi belum mampu menjadi dewasa. Fenomenanya saat ini makin banyak muncul ke permukaan melalui berbagai kasus pula. (Dokumen, n.d.) Dalam Al-Qur'an membagi fase umur manusia kepada tiga bagian, yaitu lemah, kemudian kuat, kemudian lemah dan beruban.

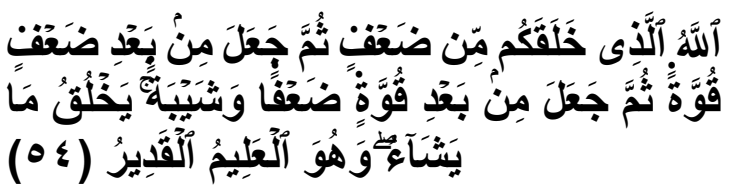

Artinya: "Allah, Dialah yang menciptakan kamu dari keadaan lemah, kemudian Dia menjadikan (kamu) sesudah keadaan lemah itu menjadi kuat, kemudian Dia menjadikan (kamu) sesudah kuat itu lemah (kembali) dan beruban. Dia menciptakan apa yang dikehendaki-
Nya dan Dialah Yang Maha Mengetahui lagi Maha Kuasa" [QS: arRum ayat 54].

Ibn Katsir di dalam Tafsirnya saat menjelaskan tentang ayat ini menulis, (Muhammad Nasib Ar-Rifa'i, n.d.) "Kemudian ia keluar dari rahim ibunya, lemah, kurus, dan tak berdaya. Kemudian ia tumbuh sedikit demi sedikit sampai ia menjadi seorang anak, lalu ia mencapai usia baligh, dan setelahnya menjadi seorang pemuda, yang merupakan kekuatan setelah kelemahan. Kemudian ia mulai menjadi tua, mencapai usia paruh baya, lantas menjadi tua dan uzur, kelemahan setelah kekuatan, maka ia kehilangan ketetapan hati, tenaga untuk bergerak, serta kemampuan berperang, rambutnya menjadi kelabu dan sifat-sifatnya, zahir dan batin, mulai berubah."

Disebut dalam fase yang pertama sebagai fase kanak-kanak, yang kedua fase dewasa, dan yang terakhir fase tua. Hal ini karena kanakkanak dan orang tua memang berada dalam fase kelemahan, sementara kekuatan ada pada usia dewasa. Namun batasan usia pada masingmasing fase dalam hal ini usia baligh, atau usia lima belas tahun, merupakan batas usia dari kanak-kanak ke dewasa dan usia enam puluh tahun, kurang lebih, merupakan saat-saat peralihan ke usia tua.

Usia lima belas tahun adalah waktu yang tidak terlalu lama sejak seorang anak mencapai usia baligh, sehingga membuat seorang anak tidak perlu melewati masa peralihan yang terlalu panjang untuk memasuki usia dewasa

Target Kompetensi Sekolah Alam Tangerang, "The Responsible Natural Shepherd" adalah: 
1. Pribadi yang karena kematangan dan kedewasaannya mampu menjadi gembala alam yang bertanggung jawab kepada Allah (Khalifatullah fil-ardh), berbekal sikap hidup yang harmonis terhadap alam dan tekad untuk menjadi rahmat bagi alam semesta. Pribadi yang matang dan dewasa adalah pribadi aqil baligh yang mampu membedakan mana benar dan mana salah dan siap menanggung konsekuensi atas setiap yang dilakukan dan siap bertanggung jawab kepada Allah SWT.

2. Mampu menjadi gembala adalah gambaran kepemimpinan yang bukan hanya memimpin, kepemimpinan "imamah". (Karim, Abdul, Nur Fitri Mardhotillah, n.d.) Ing ngarsa sung tuladha, ing madya mangun karsa, tut wuri andayani di depan memberi contoh, di tengah memberi semangat dan di belakang memberikan daya kekuatan. Dengan sikap harmonis menjadikan alam bukan sekedar untuk dieksplorasi namun juga melakukan konservasi, menjadikan alam sebagai sahabat untuk mendewasakan diri.

3. Menjadi inisiator dalam berbagai kebaikan kebaikan yang dirasakan bukan hanya oleh manusia namun juga oleh seluruh makhluk hidup. (Dokumen, n.d.)

Rumusan masalah yang penulis tuangkan dalam tulisan ini adalah bagaimana peran sekolah dalam menyusun konsep kuriulum Aqil Baligh? Dapat mengetahui permasalahan yang dialami peserta didik sebagai landasan sekolah untuk memfasilitasi permasalahan peserta didik maupun untuk mengembangkan pelajaran sesuai dengan kebutuhan peserta didik, peserta didik yang ingin berkonsultasi mengenai keagamaan akan selalu merasa nyaman ketika ingin berkonsultasi masalah keagamaan, guru peka terhadap permasalahan baligh peserta didik dan mengetahui peserta didik yang sudah baligh sehingga akan memudahkan melakukan pembinaan yang intensif, peserta didik dilatih berorganisasi supaya bisa belajar manajemen, kerjasama, kepemimpinan, pemecahan masalah,mengambil keputusan, dan sebagainya. Mengenai bagaimana peran orangtua dalam Program WWP yang diterap sekolah untuk anak-anaknya di rumah? Orang tua selalu bersifat terbuka dan bersahabat kepada anak, menjadi pembimbing bagi anaknya terlebih ketika masa awal remaja atau baligh, karena psikis anak ketika usia remaja (awal baligh) sangat sensitif dan labil, melakukan kerja sama dengan guru atau pihak sekolah ketika tidak mampu menyelesaikan permasalahan anak-anaknya, orang tua harus berani dan tegas, membangun tangung jawab biarkan anak merasakan sebagai akibat dari perbuatannya, berikan kebebasan, amanah dan tanggung jawab, belajar memecahkan masalah jangan sembunyikan masalah dari anak, saling berbagi masalah, bawa masalah ke rumah dan ajak anak diskusi untuk memecahkan masalah, dan diingatkan bahwa saat mereka baligh mereka harus bisa menghidupi diri sendiri artinya didik anak untuk mandiri dan berjuang, jangan penuhi semua permintaan mereka, ajarkan berbisnis mulai dari rumah sebagi contoh mencari uang jajan sendiri. 


\section{SIMPULAN}

Sekolah Alam yang mengajak para orang tua untuk merancang pembelajaran yang memberikan makna kepada setiap anak melalui Program Work With Parents (WWP) dan program individual yang diperlukan oleh setiap anak, yaitu dengan menamakannya kurikulum Aqil Baligh. Kurikulum aqil baligh ini untuk mendidik peserta didik sekolah Alam sebagai generasi muda agar siap menjadi generasi yang matang dan berakhlak, yang secara khusus mempersiapkan peserta didik memasuki tahap kedewasaan dan menjadi sosok dewasa yang matang dan bertanggung jawab.

Pada masa pendemi ini sistem pembelajaran berupa online juga di sekolah Alam ini, dan memang mempengaruhi pembelajaran bagi peserta didik di rumahnya.
Implikasinya orangtua menjadi tauladan bagi anak-anaknya serta ada tanggung jawab terhadap lingkungannya, sosialnya, dan budayanya. Anak akan memimpin bakatnya sendiri sedang guru perlu mengambil peran itu demi menyelamatkan pemahaman anak didiknya dari kemungkinan munculnya pemahaman dan perilaku keliru dan menjerumuskan.

Supaya memiliki pribadi yang karena kematangan dan kedewasaannya mampu menjadi gembala alam yang bertanggung jawab kepada Allah (Khalifatullah filardh), Dan kekuatan akalnya dapat membedakan mana perbuatan yang baik dan perbuatan yang buruk, mana kebenaran mana kedustaan dari sesuatu ajaran dan perbuatan.

\section{DAFTAR PUSTAKA}

Adriano Rusfi. (n.d.). Konsultan Pendidikan Aqil Baligh sekaligus konsultan Sekolah Alam Tangerang,.

Berry, K. S. (n.d.). (2004), Multiple Itelligences Are Not What They Seem Tobe, Vol. 278, multiple intelligences reconsidered, pp. 236-250 Published by: Peter Lang AG Stable URL:

Accessed: 25-04-2020 06:16 UTC.

Carol A. Bailey. (n.d.). A Guide to Qualitative Field Research (Thousand Oaks, CA: Pine Forge Press, 2006), yang dikutip oleh Abdul Fatah dengan judul tesis Budaya Toleransi Dalam Pembelajaran Pendidikan Agama Islam (Kajian di SMA Negeri I Kota TangerangSelatan), SPs.
Dokumen. (n.d.). Sekolah Alam Tangerang.

Dokumen. (n.d.). Program yang dibuat oleh Sekolah Alam Tangerang.

Depdiknas. (n.d.). (2004), Pedoman

Merancang Sumber Belajar, Jakarta.

Ensiklopedi-hukum-islam-akil-baligh-1. (n.d.). Diakses pada tanggal 19 Juli 2020 pukul 14.00 WIB dari https://republika.co.id/berita/ m71yjc/ensiklopedi-hukum-islamakil-baligh-1.

Iskandar. (n.d.). (2008), Metodologi Penelitian Pendidikan dan Sosial Kuantitatif dan kualitatif, Jakarta: Gaung Persada Press, 178

Jahya, Y. (n.d.). (2011), Psikologi Perkembangan, Jakarta: Kencana, 220. 